„Bohemistyka” 2021, nr 4, ISSN 1642-9893

Jan VOREL

DOI: $10.14746 /$ bo. 2021.4 .1

University of Ostrava

\section{From Searching for Cultural Integrity to Symbolism of Temple Building and the Organic Picture of Reality}

Keywords: Czech Literature at the Turn of the 20th Century, Decadence, Symbolism, Work of Art of Julius Zeyer, Aesthetic-philosophical Concept of Art as a Searching for Cultural integrity, The Idea of Organic Picture of the World, Motifs of Temple Building as a Symbol of Real Artistic Creation.

Klíčová slova: Česká literature přelomu 19. a 20. století, dekadence a symbolizmus, Julius Zeyer, esteticko-filozofická koncepce jako prostředek hledání kulturní integrity, umění jako vytváření organického obrazu světa, motiv stavitelství chrámu jako symbol skutečné umělecké tvorby.

\section{Abstract}

The article is focused mainly on aesthetic-philosophical constants of the work of art of Julius Zeyer. The author of the article tries to point out that Zeyer's conception of art is tightly connected with artistic conceptions of the rising literary symbolistic generation: His aesthetic-philosophical system contains strong protest against rationalism, realism and naturalism in contemporary literature and underlines the way to subconscious roots of human existence; it turns away from rational understanding of the world and the mystical intuition of inner and organic life in modern literature. In the article the motifs of temple building and motifs of creating the organic picture of the world in Zeyer's work of art are analysed. The article also contains main references to Zeyer's work of art published by reputable names of the Czech and European literary criticism.

Křest'anská renaissance, jaké jste to napsal slovo! Je krásné jako slunce. Ale uskutečnění není možné, má-li býti jen literárně míněno. Literární naše snahy mohou být jen prostředkem, jeden $\mathrm{z}$ prostředků $\mathrm{k}$ tomu znovuzrození. Není třeba ducha nového, jen průchod $\mathrm{k}$ tomu duchu starému, staršímu než svět! [...] Schází mi pořáde ještě základní tón, zbarvení svého vypracování, harmonisace, naladění celku. [..] Vždyt' tušení o tom, co chci a jak bych chtěl, aby to znělo a zpívalo, mám v hloubi duše. Je tu jen zápas $\mathrm{s}$ formou, $\mathrm{s}$ hmotou, jako při každém výkonu uměleckém (Přátelství básníků... 1997, s. 69-71).

As a preliminary point, it should be noted that Julius Zeyer (1841-1901) belongs to a certain number of authors whose work of art was mostly ignored by the Czech literatry criticism during the second half of the $20^{\text {th }}$ century. Except for several studies in periodicals, introductions, epilogues and commentaries of editions of Zeyer's work of art, there was not published any fundamental monograph depicting the specific aesthetic-philosophical system of the author who tried to unify the Czech literature with European modern artistic movements. Thus, significant monographs and studies were published in the first half of the $20^{\text {th }}$ century ${ }^{1}$ :

[...] naše literární věda a uměnověda v posledních desetiletích ztrácely schopnosti chápat umělecké zjevy a typy, v jejichž dílech umělecký výraz sahá podstatně za hranice krátkodobě přijatelných ideových motivů a dočasně př́značných stylistických dominancí. Př́liš specializovaná stejně jako zhrublá teorie není schopna hlouběji pronikat do jemné tkáně propojení duchovních a smyslových stránek umění. Zůstává hluchá $\mathrm{k}$ dílům laděným ve vyšších rovinách těchto spojení, vyhýbá se jejich interpretaci nebo interpretuje-li, poškozuje svou bezmocností další přijetí díla. V tvưrčím profilu Zeyerově je mnoho protikladností, vysoká místa tvưrčího vzepjetí génia se stř́dají s touhou i vưlí hraničící s prostotou naivismu, kultivovanost snažící se zakotvit emoce, stupňuje i sráži vzněty uchopené bezprostředně z tajemna hmoty, vesmíru, osudu. Jen slabá a morálně i odborně nejistá uměnověda se může vyhýbat takovému dílu, jakým je dílo Zeyerovo (TEXTY, SNY OBRAZY... 1997, s. 150).

Nevertheless, there is an exception represented by a monograph of the British researcher R. B. Pynsent Julius Zeyer: The Path to Decadence (1973), which tries to make Zeyer's work of art a part of European literary context of the turn of the $19^{\text {th }}$ century. The situation finally changed during 90's, when Czech literary criticism started to be intensely interested in the Czech literary decadence and symbolism and when a large number of monographs and studies were published (for particular examples see the selected titles in references).

${ }^{1}$ Further in e.g. Augusta 1918, Krejčí 1901, Voborník 1908, Marten 1916, Kvapil 1942, Jurčinová 1941. 
Even though Julius Zeyer is traditionally considered to be a representative of so called "Lumír literary generation" in history of the Czech literature, there are some aspects of his work of art that connect him with the generation representing modern literary movements in the European and Czech literature (mainly decadence and symbolism). This study focuses on proving this claim and tries to find essential aesthetic and philosophical constants of Zeyer's work of art that confirm the existence of an extraordinary creative personality of the Czech lieterature of the turn of the $19^{\text {th }}$ century.

It can be said that whole Zeyer's work of art is filled with a keynote of searching for Absolute as an idea of transcendent reality. This idea is understood itself as a Platonic idea of goodness and beauty, Gnostic principle of eternal substance and creative essence of the world, which, according Zeyer we can approach through real artistic creation:

Jsemt' stvořen jako ty bez vưle své a úpím pod břemenem bytí jako ty. V pravěké noci trůní velké, všeobsáhlé To, bez vůle, bez bytosti; vše z něho temení, vše se vně časem vrátí, ty, já, bozi, lidé, světy. Železně leží zákon na mně jako na tobě, jsem stvořen, abych tvořil, a tvořím s trpkostí, vždyt' vím, že moje světy jsou velkými jen omyly (Zeyer 1901-1906, s. 184).

The concept of this eternal substance is also shown in Zeyer's introduction to the book by V. V. Zelený O Bedřichu Smetanovi (1894):

Všechny ideály velkého umění snad ničím nejsou než předtuchou toho intenzivnějšího bytí po smrti, kde stav našeho nejvlastnějšího já bude schopnější vyšších a obsáhlejších pojímání všeho, co jest a ne se pouze zdá, ideál pak bude skutkem a symboly budou podstatou... (Zeyer 1901-1906, s. 127).

Seeking for recognition of creative essence of the world is tightly connected with the presence of motifs of pilgrimage, Wayism, horizontal and vertical movements as symbols of epiphany and breaking the borders of profane being in work of art of Julius Zeyer. The deep symbolism of transcendence of the profane reality as a way to sacral dimension of human being is projected into the majority of Zeyer's literary works (poems, short stories, novels). The projection is usually performed as a specific scheme of the plot: leaving an idyllic place as a symbol of primal harmony, staying in the labyrinth as a symbol of descendind to the darkness of mind and finnaly transition from profane to the sacral dimension of being.

Motifs mentioned above are also closely related to the personal situation of Julius Zeyer, when his inner world, filled with highminded ideals of goodness and beauty, is confronted with emptiness of reality, disillusioned with the Czech political, social and cultural life and, finally with negative attitude of contemporary literary criticism towards his literary work (,Jak se brániti proti nadutosti a nízké podlézavosti..." - Jan Maria Plojhar). Knowledge of his own adversity in the field of the Czeh social and cultural area led him to the feeling of estrangement and rootlessness that could be demonstrated by a quotation from the letter to Marie Kalašová in 1888, when his novel Jan Maria Plojhar was written:

V Praze mi někdo řekl: Vy jste nám nějak cizí, jako byste mezi nás nepatřil. Nevím, co tím říci chtěl, bolelo mě to tak, že jsem se neptal po vysvětlení. Bylo mi jako dítěti, které matka odstrčí, a od té doby znám určitě onen pocit, který byl dříve pouze mlhavým a který jsem vám právě naznačil (Ve stínu Orfea... 1949, s. 91).

Altghough Julius Zeyer was very often considered to be a "strange figure" in the Czech literature by contemporary literary criticism, he denies this affirmation by his own regard of well-educated and cultured "European" to that:

Naše literatura bude se ztráceti v tom moři a někteří u nás doma proto tak s patra se dívají na ni - ale neprávem. Česká literatura je pro český národ v prvé řadě a tu koná svůj úkol zajisté horlivě a ne bez všeho zdaru. Což nepovzneslo se niveau umělecké u nás na značnou výšs? Naše kritika se na nás ubohé literáty zle hněvá, že nejsme, geniové - což to čí vina? Tu se musí čekat, čekat a čekat. Genius bez připravené půdy se nezjeví a pouhá literatura ho nezplodí - to je věc celého národa, $\mathrm{k}$ tomu třeba uzrání ducha národního. Genius mluví za celé generace - ale dřive musí těch generací být, co by genius za ně promluvil (Přátelství básniků... 1997, s. 52).

The solution of all of mentioned conflicts was for a "passive dreamer" Zeyer his personal desire for solitude and, above all, escape from everyday reality to dreams, ancient myths and legends, which in his deepest essence represents the poetization and aestheticization of 
profane and banal reality. This situation illustrates Zeyer's letter to famous Czech painter Zdenka Braunerová:

Neštasten vyjel jsem z Čech a nešt’astnější se tam vrátil. Nač jsem to svoje prokletí vlekl až k Vám. Byla to pravá inspirace, když jsem si řekl, že mezi živoucí už nepatřím, a když jsem chtěl se utéci mezi stíny do kláštera. Co mám Vám říci? Co byla príčina, že jsem tam nešel? Jedna z nich byla illuse umění, to mě stále poutalo k životu (Přátelství básniků... 1997, s. 39).

In May 1889 he writes following words to his friend František Herites, that could become the creative creed of the rising generation of decadent and symbolistic writers:

[...] cítil jsem vždy jako poeta a co takový se na svět díval, to moje útěcha... V nás celý svět a mimo nás je klam (Pŕátelé Zeyer-Herites 1949, s. 64).

Similar ideas are expressed by the main character of Zeyer's work of art Báje Ššsany - Valerius:

Básně jeho byly sny a sny jeho byly básněmi. Nikdy nepřišla mu myšlenka znesvětiti vidiny své černidlem tiskařù, prosívat je sítem grammatik, skomolit je dle předpisů tak zvané esthetiky a podat je pak zmrzačené, vyrudlé do rukou lhostejného skeptického obecenstva, by nad nimi nosem krčilo, a cynických kritikastrů, by s nimi své kejkle prováděli (Zeyer 1901-1906, s. 3).

The whole work of art of Julius Zeyer, including its thematic widenes, has a compact nature. From the point o view of genre this compact nature is confirmed by clear domination of the epic. Lyric poems represent a small, but substantiall part of his work of art, that claims e.g. Josef Hrabák in his epilogue to Zeyer's Román o věrném prátelstvi Amise a Amila (1880):

Zeyer má také smysl pro kompozici velikých celků, což scházelo Vrchlickému (který se pokusil o rozsáhlou epickou skladbu jen výjimečně) i Sládkovi. Zeyer byl rozený epik, a proto také uměl vidět svět okolo sebe plasticky a ve velkých proporcích - i po té stránce byl jakýmsi stavitelem chrámů. V předmluvě ke Karolínské epopeji píše, že epika je vi̊bec přibuzná k architektuře (Zeyer 1983, s. 272).

As far as the lyric, "little epic" and drama achieves, in the contexct of The Czech literature of $70^{\prime}$ s and $80^{\prime}$ s of the $19^{\text {th }}$ century, high level of their development, there is the blank space of the "great epic". The work of art of generation of writers called Ruchovci and Lumírovci, which in $70^{\prime} \mathrm{s}$ and $80^{\prime} \mathrm{s}$ of the $19^{\text {th }}$ century had a dominant position in the literary development, represents effort to overcome this deficiency. It is the reason why in this period a large number of epic works were written. Compared to the work of art of other authors of mentioned literary generation, Zeyer's epic has really different specific attributes; thanks to them we can speak about the existence of original literary form, in Zeyer's words a "renewed picture". This literary form could be easily characterized as a free processing of ancient mythological, legendary, historical and literary themes of several times, nations and cultures.

Certain borderless nature of selection of historical, geographical and ethnographic themes could be considered as a symptomatic feature of "Lumírovci". In case of Zeyer's work of art, there are some specificities influenced by his creative intention. From geographical and ethnographic point of view, the main thematic resource is represented by Romanesque, Anglo-Saxon, Scandinavian and Slavonic (Czech and Russian) culture tradition in his art work. We can also see a very strong interest in oriental and Eastern spirituality there.

However, the specifity of Zeyer's work of art rests in historical and culture point of view. Thematic predominance of pagan and gothic themes is typical for Zeyer's creative artistic activity. For Zeyer the paganism and the Gothic are the epochs when strong spiritualism overcomes a material essence of human life. Mainly the Gothic, shined whith early Christianity and chivalry, represents a way to ideal culture embodied in the symbol of synthetic picture of temple building. Later the same symbol became the main idea of the work of art of the Czech symbolist poet Otokar Březina as an idea of "higher humanity" and interconnection of material and spiritual aspects of human being:

Ve starověku bylo umění proto tak velké, že lidé ještě bezprostředně silně po lidsku cítiti dovedli, a v křest’anském středověku bylo tak produševnělé, protože pluli lidé po bezedném moři mystiky s tak silnou vírou (Zeyer 1901-1906, s. 121).

However, Zeyer's creative conception has its deep meaning, which makes his work of art to a certain extent a prologue to Czech literary symbolism. 
The term "renewed picture" as a specific element of the author's poetics could be understood as an evocation of an ancient myth, an updating of the story well- known in world literature and folk tales. Nevertheless, Zeyer doesn't narrate with clear epic distance, everything is accompanied by his personal reflections and reminiscences of his own experiences and participation in narrated story. Thus, in Zeyer's work of art the lyric component permeates the clear epic base, which helps to create the compact picture of reality in human counsciousness.

Jan Voborník in his monograph Julius Zeyer (Voborník 1907) turns attention toward the existence of three interrelated levels or,more precisely, three types of poetic representations of reality in Zeyer's work of art. They are represented by direct reflection of reality, by the world of philosophical idea and mythological structure and finally by the world of author's own inner visions. We can also understand these three types of poetic representations creating a compact picture of reality as an analogy to the concept of a symbol and the process of symbolization in theoretical thinking of famous symbolist poets (e.g. O. Březina, A. Bely).

Thus, it seems that aspiration for integrity is one of the most important parts of Zeyer's creative conception. In his "day dreaming" (because dream became a symbol of poetry and beauty for him and the link between everyday and transcendent reality), he interacts disparate springs that finally joins together to one mighty archetypal creative stream.

In the introduction to his cycle of epic poems Karolinská epopeja (1896) Zeyer in more details explains the essence of his creative conception. Even though Zeyer feels that contemporary art is too weak to reflect the fullness of life, he finds some positive moment there that could lead it to the spiritual renaissance. As this positive moment he can see an increasing interest in values that were brought by ancient cultures and implement these values to the present time and present them as an integral picture of human civilization. This role of reinvigorate intercultural communication was essentially fulfilled by the aesthetic programme of "Lumír" literary generation, but Zeyer's creative conception goes deeper to the spiritual essence of culture:
[...] a zbývá nám něco jiného než nastavovat všechna vlákna a navazovat všechny svazky, které nás pojily vždy s kulturou všeevropskou a jež přet’aty byly, když nás do hrobu kladli? (Zeyer 1905, s. 22).

Here Zeyer also underlines the fact that there is always something which exists over contemporary trends and which is higher than mere observing surface of things. This is the "inner truth" hidden inside every civilization, religion and every artwork. The essence of art is for him its ability to gravitate towards the Universality and ability to resurrect ancient pictures of Beauty that could create the state of integration of material and spiritual words in the soul of modern humankind:

[...] člověk, třeba by se zdál sobě neb jinému jinak než vpravdě je, zůstane přece jen tím, čím je, a ne tím, čím se zdál, a mimoděk, nevědomě se prozradí a ukáže ve svém jednání, ve svém smýšlení, ve svém díle v pravé podobě (Zeyer 1905, s. 20).

The same position to Zeyer's work of art is taken by F. X. Šalda in his critical study Julius Zeyer (1901). For him Zeyer represents a type of author of typically wide and reconstructing imagery. This kind of imagery is the evidence of birth of mighty poetic soul in the Czech literature who is resurrecting ancient picture to the fullness of life and who is escaping to the past because of his inner desire caused by his distress and his scorn for present time:

Tento člověk byl v první řadě raněná duše básnická a v druhé řadě teprve vzácný sběratel a znatel umělecký, stylový, kulturně historický. Jen proto podařil se mu mnoh- dy zázrak magického oživení minulosti, tlící pod rumy tisíciletí (Šalda 1951, s. 25).

Šalda also tries to find connections of Zeyer's creative conception with general development of art of the turn of the $19^{\text {th }}$ century and he concludes that Zeyer in his artistic development went through romantism to artistic tradition of parnasism which underlines historical and cultural psychology in artistic creation. Acording to Šalda for Zeyer's work of art the process of deepening, interiorization, psychologization, the way from superficial representation of exotic and historical sence to its deeper complete meaning:

Od dekorace a stafáže přešel k psychologické intimnosti, $\mathrm{k}$ duchu a srdci. $V$ těchto svých pracích chytá Zeyer obyčejně základní psychický akord, key-note, mohutný 
a krajní, prostý a silný, a staví na něm a harmonisuje jím celou práci, která stává se tak neobyčejně jednotnou a výraznou v náladě a barvě (Šalda 1951, s. 26).

For Šalda Zeyer presents, above all, the author of epic literary works par excellence who, thanks to the creative reconstruction of ancient myth tends to a harmonic and unitary world of ancient cultures and who regards all life process through the prism of religious experience. Šalda also underlines Zeyer's orientation to organic and archetypal vision of life:

Zeyer je neobyčejně ryzí a celý epik. Bez skeptického rozumářství, naivně oddaný všemu velikému, silnému a mystickému, vmyslil a vesnil se s velkou láskou $\mathrm{v}$ zapadlé světy hrdinské, v kultury primitivní a jednotné. [...] Nazírá v život s náboženskou úctou $k$ veliké organické jednotě přírody, člověka a osudu; vidí všecko v toku, bez pevných forem ještě, s tajemstvím významu... (Šalda 1951, s. 30-31).

Zeyer's "renewed picture" as a searching for a spiritual essence of life is, in fact, a literary strategy tightly connected with aesthetic conceptions of symbolism itself. It is the way of treating of mythical or historical material determined by an effort to renew and maintain selected material in any time, to highlight its spiritual outreach and transform it to the timeless and noetic level. Another typical feature of Zeyer's work of art which leads him towards literary symbolism is dreamlike atmosphere of his literary works, the estetization of everyday reality, suggestive moodiness reached by harmonization of lyric and epic elements (e.g. convergence of emotional world of characters and sceneries). Dominant role in his work of art plays, as much as in the work of art of majority of symbolist writers, deep symbolism of colours and forms. Tomáš Vlček in his study Výtvarné uměni v životěa dile básnika vizi a snů points to the fact that for Zeyer's work of art (like for J. Mařák, J. Schikaneder and K. Hlaváček) is typical his refined sensitivity for spiritual energy of coulours:

Azur prochází vizemi kosmických představ zrcadlících éternou povahu smyslovosti. Zcela mimořádný význam má bílá jako dominantní duchovní symbol. [...] Božské energie nerozpoznával jenom psychickým stavem chvilkového smyslového rozpoložení vnímání světa, ale především v trvajících a opakujících se stavech tvůrčího myšlení, v nichž hledal návaznosti světa př́rody a umění. Podobně jako Ruskin viděl v křivkách prvky, které spojují Božskou existenci s přírodou, Zeyer nacházel porozumění pro tvarové, barevné a světelné hodnoty viditelného světa, s duchovními významy (Vlček 1997, s. 172).

We can also see the tendency to an organic expression of reality in ancient pagan myths, fairy tales, Christian legends and historical legends. For Zeyer this is the only way how to understand the genesis of human culture and find the spiritual grounds of civilizations. This fact is confirmed by a quotation of prologue of his drama Radúz a Mahulena (1896):

Jsem pohádka. Kdo se mnou půjde, povedu jej do modrých krajů báje. Zde z těchto olbřímých štítů po starých cestách, mechem porostlých a listím dávných jesení zavátých, sestoupím dolů, tam v slunné nivy slovenského lidu. Znám tůně jeho duše a pradávné jeho sny v mém nitru žijou. Vždyt' stála jsem u jeho kolébky! Závojem čarným obestírám děje věků zapadlých do mlžin paměti. Pod třpytem jeho řas však ty dávné lidské touhy křídla svoje rozpínají a lidská něha plá zpod jeho záhybů a lidské slzy tekou lesklou jeho tkaninou a vroucí, věčně lidská srdce bijou, tu vášnivě, tu snivě pod krytem jeho volně vlajícím... [...] Jsem pohádka a rodná sestra těch, jež Ganga kojila, i těch, co na iránské vysočině snily, kde nejjasnější hvězdy hoří, i těch, co ve skandinávských divočinách půlnoční rudé slunce znaly, i těch, co v řeckých hájích vedle dávných moří v bílých chrámech $\mathrm{z}$ mramoru jak vlaštovice hnízdily i posléz těch, co v mračných doubravách, kdy druidi bledou lunu ctili, kol šedých menhírů své reje křepčily... Jsem pohádka dým mystický se nese přede mnou, a za mnou duje vítr pravěký... Kdo za mnou chodí, vidí dávné sudic předivo... (Zeyer 1961, s. 27-28).

In searching for timeless and mytological roots of art, Zeyer follows up the aesthetic-philosophical theories of Richard Wagner and Friedrich Nietzsche. His work of art reflects Wagner's theories of synthetic art (Gesamtkunstwerk) and Nietzsche's concept of an intellectual dichotomy between the Dionysian and the Apollonian. A Czech writer and essayist Miloš Marten in his study Akkord: Mácha-Zeyer - Březina: Essaie (1916) notes that poetic phyziognomy of Zeyer's work of art is made of two mythological traditions and it is displayed outwardly by strong sensuality on one hand and mystical immersion in the deepest secrets of life on the other hand:

Spojuje latinský idealismus něhy a síly, vášnivé, jasné a prosté rytiŕství ducha, které tak nádherně se rozvinulo s kulturou první renesance, s živly severní, slovanské tesknoty, s pochmurným mysticismem, který se obrací do nitra a lidskou duši sídlem démonovým, exaltuje soucit a obět', miluje temné a záhadné hloubky bytí (Marten 1916, s. 30). 
The myth helps Zeyer to find the uniqueness and timeless beauty of eternal truth. His understanging of the myth is closely connected with his attitude to Czech cultural and historical tradition. Behind Zeyer's cosmopolitanism and patriotism, we can see cultural consciousness of a European and an effort to understand Czech culture, history and myths as a search for common roots of European culture, which is a part of higher Indo-European entity. This higher entity filled with strong spirituality could, according to Zeyer, renew the contemporary materialistic Europen culture:

V každém člověku, odpověděl, jsou zárodky jiných ještě smyslů než těch pěti nejvyvinutějších, známých a za jediné v nás pokládaných. Př́liš málo si však těch zárodků všímáme, obzvláště ted' $\mathrm{v}$ tom materialistickém barbarském proudu doby, kterým plujeme, kterým, pravda, pluje vždy většina lidí, abych nebyl nespravedlivý k naší době a abyste nemyslil, že jsem z těch, kteří pořáde jen po minulosti touží. Přeji si pouze, aby v nás árijský duch, význačně spiritualistický, nabyl opět vrch. Jsou př́iznaky, že se tak pomalu stává. Poklady moudrosti indické, tak čistě árijské ve svém ideálním altruismu, v nesmírné vznešenosti abstraktního pojímání, obnoví snad od začátku naší kulturu (Zeyer 1901-1906, s. 144-145).

The myth also plays an important role in Zeyer's work of art when his literary work seems to be autobiographical and when he turns attention to the contemporary themes. As an example we can see it in his novel Jan Maria Plojhar (1888) where Zeyer mythologizes its narrative and presents all characters in archetypal level. Each of them represents either absolute goodness, love; or absolute evil and hatred that connects them with mythological understanding the world as a struggle of evil and good. In this novel, for example Mrs. Dragopulos becomes a symbol of a dark force and fatal passion and Caterina turns in Plojhar's imagination to Dante's Beatrice as his guide to an afterworld empire of the Great Beyond. Thus, these motifs tend this contemporary narrative to the mythical level, to the Tristan legend of love and meld in death. Destiny of the characters of Zeyer'novel Ondrej Černyšev (1875) contains New Testament and Gnostic symbolism (motif of the Passion of Christ, motif of Our Lady of Seven Sorrows, myth of Redeemer etc.).
Helena Lorenzová in her study Solární mýtus v díle Julia Zeyera also defines Zeyer's attitude to myth and she underlines the fact that his work of art really stands in the light of European modernism:

A zde jsme i u základního rozdílu mezi Wagnerem a Zeyerem. Wagnerovi posloužila teorie slunečních mýtů $\mathrm{k}$ dalšímu posílení nacionalismu a vlastně tak dovršuje ideologické tendence 1. poloviny 19. století. Zeyerovi táž inspirace otevírá cestu od šovinismu ke kosmopolitismu, od evropocentrismu k zájmu o mimoevropské kultury, čímž se přibližuje století dvacátému, kdy se tzv. neomytologismus snaží bud' o transkulturní syntézy (např. Eliot, Pound, D. H. Lawrence) či o ironickou konfrontaci aktuálního, deheroizovaného života člověka 20. století s mýtem (jak je tomu např. v díle F. Kafky či J. Joyce) (TEXTY, SNY OBRAZY... 1997, s. 40-41).

If we accept that Julius Zeyer created the prologue to the Czech symbolism, we have to ask in what way the elements of symbolism are manifested in his work of art. In the first place, Zeyer strictly comes out against the Newtonian, materialistic model of cosmos and in his work of art he always tries to transcend the borders of sensual and empiric reality. He was convinced that art influences us as an "inner revelation". According to Zeyer, the essential mission of each artist is the knowledge that every thing hides secret signs that could lead us, by the way of contemplation, to the spiritual and archetypal essence of the world:

[...] vždyt' vskutku nejsme ničím jiným, než bud' stopou aneb obrazem jednojediné bytosti. [...] Vše, co se býti zdá, není snad více než myšlenkou onoho jediného mozku - obrazně řečeno - v němž všechny světy jako komáři v letním slunci krouží. Vědomí, že jsme-li, jsme tolik jím, povznáši nás z bouřlivého moře vášní a klamů $\mathrm{k}$ výši, odkud zříti lze nehybný blankyt širého nebe, ten symbol všeobsahující, bezkonečné bytosti, z kterých všechno vzešlo a ku kteréž co možná se opět přiblížiti jest tužbou moudrých (Zeyer 1949, s. 150).

We can undoubtelly understand these signs as the symbols and the artistic creation, as a symbolization, which means the process of creating art images that we cannot realize by traditional cognition; but in our consciousness they generate in an organic image of the world:

Myslíte pod realismem $p r a v d u$ v umění, jakoby teprve naši moderní realisté ji tam uvedli. Hled'te jen dobře na tu sochu sv. Františka; tu ukazuje se nám rozdíl mezi těmi dvěma dobami. Moderní škola, aspoň ti z ní, kteří nejvíce heslem házejí, myslí jen na pravdu v provedení předmětu, jakéhokoli. Ti velcí mistř̌i neměli hesel, ale nazíral bezprostředně a jednalo se jim především o to, je-li to, co tvořiti chtěli, také dosti 
vynikající nad povrch, neb prostě řečeno, stojí-li ten prredmět za to, aby byl utvořen. Většina těch běžných výtvorů nyní v módě jsoucích za to nestojí. Co autoři jejich $p o-$ zorují tak podrobně, nemůže vlastně nikoho valně zajímat. Hled’te na toho svatého Františka, jaká pravda v provedení, vid’te - ale především, jaký ideal v koncepci! A v tom leží celé umění (Zeyer 1901-1906, s. 153-154).

Through the "renewed picture", Zeyer achieves a universal view of the world and he also transorms the sence of art creating to open up its spiritual and cosmic dimension. According to Zeyer, a true artist reaches this spiritual and cosmic level and, filled with mystical knowledge, he returns back to the reality to search here for inner energy and for the spiritual meaning as a method for creative and spiritual metamorphosis of the world.

Zeyer's work of art is connected with the rising symbolism also by the idea of synthesis which is symptomatic especially for the aesthetic-philosophical system of the real symbolists such as Otokar Březina, Vladimir Solovyov and Andrey Bely. The reason why this thought became fundamental for Zeyer is based on his deep interest in ancient mystical movements, hermetism, Eastern spirituality and also in contemporary philosophy influenced by the strong wave of irrationalism with the sense of interconnection of material and spiritual aspects of life. In his short story Düm U tonoucí hvězdy (1897), we can find a very interesting reflection which could certainly be seen as an aesthetic-philosophical manifesto of decadence and symbolism:

Věda a literatura, umění vůbec, ba i politika a sociální naše hnutí - to vše je v stadiu pouhé analysy. Boje národnostní, spory sociální, skepse v náboženství, naturalism v umění, empirism ve vědě: tot' sama analysa. Velikost je však jedině v synthesi, kter následuje po analysi. Jsou duchové ve všech jmenovaných oborech, kteří nad svou dobou stojí, ač nedosáhli nikde vrcholku, tam dospěje svět snad za nějaké století pyšný ten strom někdy vyroste, dnes pouze klíčí (Zeyer 1901-1906, s. 154)

Finally, the motif of temple building became for Zeyer a symbol of the unity of horizontal and vertical dimensions of life, which is understood as a creative power transforming profane being to the sacra one. ${ }^{2}$ This symbol probably hides Zeyer's idea of the meaning of artis-

${ }^{2}$ Similar thoughts later also presents close friend of Zeyer and famous Czech symbolistic sculptor František Bílek in his lecture Stavba budoucího chrámu v nás printed in the rewiev Meditace in 1908). tic creation as a spiritually oriented activity and his vision of the temple is a vision of a mighty building which grows from the womb of nature and reaches the heaven filled with longing for the sacred unity (,výkřrik země k nebi chrám vlastně značí‘):

$$
\begin{aligned}
& \text { v své těžké šíri značí basis zemi, } \\
& \text { sloup, rostoucí z ní vzhưru k architrávu } \\
& \text { tak volně světlem, vanoucí větry - } \\
& \text { to člověka jest obraz vztyčeného, } \\
& \text { sám architráv, kam sloup se vzletně snaží } \\
& \text { jest symbol nebe, nad sloupem a basí } \\
& \text { je povznesen a nad ním v slávě trůní } \\
& \text { pak trojhran tympanu: trojice svaté } \\
& \text { taj nevyzpytný tak se zobrazuje, } \\
& \text { tak končí chrám a jako velké amen } \\
& \text { kříž nad ním ční do hlubin nekonečna... }
\end{aligned}
$$$$
\text { (Zeyer 1941, s. 76) }
$$

In his last novel Troje pamèti Víta Choráze (1900), Zeyer very clearly formulates this creative intention. In the course of his earth life, the main character Vít Choráz goes through "threefold memories" that symbolise three levels of human being. The first level is connected with the material principle of life and it culminates into deep disillusion. The second level presents searching for an ideal of beauty and $t$ the third level turns to inner Christianity which brings eternal, transcendent thruth hidden behind the material existence. In this level "the paradise of heart" is found and the idea of beauty is connected with the ideas of thruth and goodness.

The main character of the novel gets rid of the chains of subjective interests in favour of transpersonal interests. His unclear longing which he felt in the "first memories" gets a solid shape of idea of reu- nion of material and spiritual dimension of being. Vít Choráz becomes a creative human being who is able to transform the reality by his creation:

$$
\begin{aligned}
& \text { A v lůně ideálu stvořených } \\
& \text { děl ještě budoucích jsem viděl lidstva } \\
& \text { chrám zbudovaný na základě lásky } \\
& \text { a velkých vzletů, království to boží,... }
\end{aligned}
$$$$
\text { (Zeyer 1941, s. 78) }
$$ 
In fact, the motif of temple building is, a symbol of updating of primordial unity; it is a fusion of sensual reality with with the meaning of life and the meaning of the world:

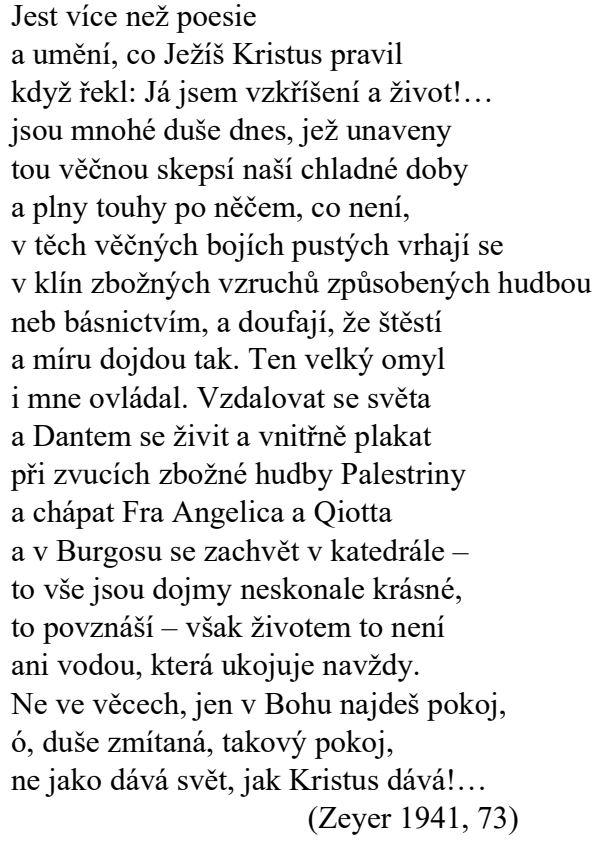

The idea of synthesis became also very important for the motivic structure of Zeyer's short story Opálová miska, which is a part of his short story collection Fantastické povidky (1882). The "bowl of opal" represents here a sacral object which hides a memory of the moments inside when humankind, thanks to the unique persons, endowed with the power of comprehensive understanding of the world (see The Self in Jungian psychology) touches the ideal and fills life with meaning. Fot the main character of this short story, filled with scepticism to humankind, becomes a revelation of a mythical old man (a symbol of Jungian "inner voice"), who presents him a history of five persons that founded a connection between the material and the ideal world, an impulse for searching for the meaning of human existence:
Po těchto slovech klesl stařec $\mathrm{k}$ zemi, podepřel hlavu o sloup a mlčel dlouho. Dech jeho se krátil a myslil jsem, že již nepromluví, ale sebral ještě jednou síly své a zašeptal: Vezmi opálovou misku, postav ji na nejvyšší vrchol nejvyšš́ho horstva světa, by věčně nad člověčenstvem jak hvězda svítila. Není možná nad lidským pokolením zoufati, dokud patero těch nehynoucích jmen vněm zníti nepřestane... Stařec mlčel znova, otvor vedoucí v poušt' plnil se bílou mlhou a zdálo se mi, že pět záŕících stínů $v$ tmavou sín jak paprsky luny vklouzlo. Stařec zašeptal cosi, oči jeho zajiskřily se a pak nehnul se více... Vzal jsem opálovou misku z jeho rukou a pozvedl ji proti slunci... Zdálo se mi, že se šiří, že roste, klenula se nade mnou jak bílá obloha sáhající z východu na západ a patero sluncí zářilo z ní a svět plnil se oslňujícím světlem... (Zeyer 1901-1906, s. 111).

\section{In 1898 Zeyer writes to K. Dostál-Lutinovov:}

Život sám Vás uvede na pravou cestu, že poznáte prázdnotu té vědy, která chce osvěcovat a nám nahraditi víru. Chtěl byste $\mathrm{v}$ širý svět a poznat nové a nové dojmy! Ale svět náš nejširší je v nás. Všechen hluk je planý, jen ten tichý šeptající hlas v nás má význam (Přátelství básníků... 1997, s. 125).

Thanks to his deep erudition in the field of art, philosophy and religious thinking, Zeyer belongs to a number of writers who in their work of art, created a comprehensive picture of the world. If rising symbolism in European literatures insisted on the throwback to idealistic art, the creating of the universal models of the reality and the turn of artistic creation to the theurgical creating, in the context of the the Czech literature of the end of the $19^{\text {th }}$ century, Zeyer represents a creative personality that largely fulfills this artistic programme and anticipated fundamental changes in its aesthetic-philosophical canon. Zeyer is also very often considered to be a representative of late romantic literature. But this claim, same as his clear assignment to "Lumír literary generation" may question Zeyer's exlusive position in the Czech literature of this period. Naturally, we can see some elements that Romanticism brought to the literature in Zeyer's work of art. However, it is clear that he takes up with literary strategies connected with modern artistic movement and he realizes their importance for artistic creation. Furtehrmore, in 90's Zeyer, gets close to the rising literary generation which finds a strong inspiration in his work of art. The fact could be declared, for example, by his friendship with František Bílek and Otokar Březina. 
Zeyer's "romantic symbolism", as it is called by Marie Kalašová (Ve stínu Orfea... 1949, s. 64) is increasingly appreciated in contemporary literary context. While the art work of Jaroslav Vrchlický is criticised and art work of J. V. Sládek is rather accepted with respect, Zeyer thanks to his asthetic-philosophical conception of art comes near the creative conception of Katolická moderna and Moderní revue. Zeyer's specific position in the Czech literature and a permanent need to be interested in his work of art is underlined in Marten's essay Akkord: Mácha - Zeyer - Březina: Essaie (1916) Miloš Marten was a member of decadent literary group Moderní revue: „Zeyer tvořil most mezi Máchou a Březinou“ (Marten 1916, s. 35). Finally, similarly sounds the statement of Eva Jurčinová in her biography of Julius Zeyer Julius Zeyer - Život českého básnika (1941); Zeyer is considered to be "John the Babtist of Czech literary symbolism" (Jurčinová 1941, s. 107). Next famous representative of Moderní revue Jiří Karásek ze Lvovic also pays attention to the work of art of Julius Zeyer and he regards Zeyer as an extraordinary creative individuality, as a poet of deep religious visions and philosophical restlesness. According to Karásek ze Lvovic, Zeyer sacrificed all his life for his artistic creation and he left behind him a "legend of proud spirit injured by all crises and pains of an epoch, the legend filled with dreams and strong lyrical inner fire of fate". Jiří Karásek ze Lvovis also regards Zeyer, similarly as Jan Neruda, to be a precursor of modern literary movements in the Czech literature. According to Karásek Zeyer brought the sense of delicate articism into the literature, aristocratic aestheticism, subjectivism, refined culture and real artistic style. He is considered to be a "painter who renovates archaic altar paintings and who enriches them with his vivid and bright colours at the same time":

Julius Zeyer... Poeta zrozený se št’astnou a věřící duší minulých, zašlých dob... Jsou, kdo se staví s úctou u tohoto čistého zjevu básnického, jenž řekl vše, co chtěl, v nahé a otevřené př́mosti, jenž realisoval do poslední linie, do posledního záhybu to, co měl v plánu, bez jediného kompromisu, bez jediné koncese... A jsou, kdo jej zase absolutně podceňují, [...] kdo se dívají s despektem na umělecká díla, jako jest Román o věrném přátelství Amise a Amila, [...] Byla to př́lišná kultura, př́lišná erudice, jež činila nepř́ístupným Zeyerovo dílo. [...] Zeyer sám cítil, že př́liš artistní aristokracismus jej činí nepř́istupným. Řekl to v povídce ze života Michelangelova Sníh ve
Florencii ústy básníka Poliziana: Výsost znamená osamění, velikost znamená nenávist. V̌se odpustí ti dav-jen to ne, že nad ním stojiš, že se mu vymykáš. Ta výlučnost ti bude trnem v životě. Orfeus nesnižil se k bakchantkám, a proto jej rozsápaly. Když se potkávala dramata jeho na jevišti s neúspěchem, Zeyer psal je dále, v stejném směru, bez koncesí, věda, že by bylo podlostí proto mlčeti, že nemůže na aklamaci davu počítati (úvod k básni Kronika o svatém Brandanu). Nehoníme se za úspěchem, pravî v povídce Večer u Idalie ústy Gracianovými. Nebot' žízníme po ideálu a ne po potlesku... Nechce se každému do letu v modré mlhy a duhová oblaka, do kterých bych prý rád zavlekl ty, jež mi naslouchají. Nuž, dobře, at' za mnou neletí ti, kteří nemohou, ti, kteří nechtějí, mně se po nich tak málo stýská, jako jim po mně... (Karásek ze Lvovic 1926, s. 110-111)

Zeyer's work of art fascinates by its essential dreaminess, cultural exoticism as an expression of desire for escape out of the boundaries of possible, by its proud sorrow and weak melancholy filled with beauty:

Jsou stránky u Zeyera, které jsou s toho hlediska pravými hody delikátního, jemného umění. Tam hoří slova $\mathrm{v}$ původní své kráse, a věty zpívají v rytmech, kř́sících obrysy a linie a vyzdvihujících předměty z mrtvé šedi k novému životu, v neztenčené intensitě svěžího ještě dojmu (Karásek ze Lvovic 1926, s. 117).

For Karásek ze Lvovic Zeyer represents a poet of pastime and dreams who is able to melt everything he touches to a "spiritual distillation of odour, softness and sweet swoon":

Ovšem ta realita jest umělá, je fiktivní, ale v umění přece neběží o laciné otisky každodenní všednosti. Jde o vnitřní opravdovost, ne o zevnější. [...] Jako Neruda, jest i Zeyer předchůdcem moderních literárních směrů. Svým uměleckým, estetickým smyslem, jemností, pozdní dráždivostí svého cítění, rafinovanou kulturou, překypělými, přeplněnými svými stilisacemi, tím vším souvisí př́mo $s$ tím, co později dostalo v literatuře jméno dekadence, a co není než romantikou nervovou proti staré romantice citové (Karásek ze Lvovic 1926, s. 119-120).

Karel Dostál-Lutinov as one of the representatives of Katolická moderna wrote about Zeyer in connection with critique of his long short story Dïm U tonoucí hvězdy following words that, the same as the essays of Marten and Karásek ze Lvovic, clearly define the character and the contribution of his work of art as a path of the Czech literature to the modern European literary tradition: 
Vypijte knihu tu naráz jako doušek lahodného vína. Ta krásná, plynná, zvonivá Zeyerovská dikce! Nemá přiléhavých lidových výrazů, zaznívají v ní cizí tóny, snadno se překládá do cizích jazyků, - a přece o ní nelze říci, že je nesprávná, nebot' je krásná, šlechtící náš jazyk. Je podobná červánkům. To pravím kritikům, kteří ji chtějí pitvat nožem. Též tu knihu doporučuji těm, kdož u p. Zeyera postrádali psychologie a filozofie. Je to vlastně kniha vážná, filozofická, obírající se záhadami náboženskými. Odhaluje duši autorovu z nových sympatických stránek. Vidíme tu p. Zeyera na několika místech prrímo radikálem. Mně on vůbec ve své poesii připadá jako bohatý krásný cizinec, jenž zabloudil do naší vlasti. Zamiloval se do ní a do nás - a my chudí nevíme proč. Přinesl mnoho perel a zlata a bájí a rozdává plnýma rukama. Přirostl k nám. Přišel z dalekých krásnějších končin, po kterých toužíme (Přátelství básníků... 1997, s. 95-96).

F. X. Šalda, the leading personality of the contemporary Czech literary critisism was deeply interested in the work of art of Julius Zeyer. At the end of his above-mentioned study Julius Zeyer, Šalda tries to answer the question to what extent Zeyer interprets the raison d'etre of his epoch and to how his "creative dream" possesses and transforms the reality. The answer Šalda finds, finally, in Zeyer's novel Jan Maria Plojhar and in his long short story Dưm U tonouci hvězdy. In both literary works he sees the projection of Zeyer's aristocratic vision of life, the projection of hopeless and doubtful soul and the projection of "twiligt and passing epoch". According to Šalda, the main charactesr of these literary works represent delicate types of persons of passing time without organic culture who feel a tragic conflict between individual and society, a conflict between fullness and beauty of inner life and emptiness, cynism and vulgarity of material life. Mainly Jan Maria Plojhar is seen as a character of modern type of the novel:

[...] senzitivní dekadent, člověk př́liš jemný a slabý pro hrubý život, nahlodaný nemocí snu nahlodaný nemocí snu a chiméry, přemetný a zrazený, hned roztoužený, hned zhnusený, stále dychtivý a nikdy neukojený, bez vnitřní kázně a silné ideové sebevlády. [...] Zeyerův Plojhar je dekadent, který ztratil čistý poměr k životu a ženě, a je spasen, alespoň duševně, velikou, obětavou láskou čisté ženy (Šalda 1951, s. 34-35).

The main character of the second work searching for deliverance from inner emptiness by means of occultism became a deep symbol of moral decline of the contemporary society. Although Zeyer did not have deeper sense for art of nuances and psychological analysis and his role in the Czech literature is rather a little lone, according to Šalda, his work of art, filled with residues of Romanticism on one hand shows elements of modern literary movements (decadence, symbolism, neo-Christianity, neo-realism) on the other hand. Zeyer is connected with the rising literary generation thanks to his aestheticphilosophical system which insists on the protest against rationalism, realism and naturalism and which underlines the way to subconscious roots of human existence, turns away from rational understanding of the world and the mystical intuition of inner and organic life:

V tomto smyslu setkává se více méně Zeyer se snahami dneška. Nemá sice přímých literárních dědiců v nejmladší generaci spisovatelské, ale vliv jeho - vedle jiných - lze cítiti přece. [...] Nebot’ ta zásluha nemůže být nikdy odňata od něho, že $\mathrm{v}$ době malé a stř́zlivé, $\mathrm{v}$ době spisovatelského mechanismu a rutiny, $\mathrm{v}$ úzkém českém světě, tak nevšímavém $\mathrm{k}$ umění a poesii právě jako ke všem velikým absolutním hodnotám života, pracoval a bojoval o uměleckou a básnickou kulturu v celém významu a dosahu slova (Šalda 1951, s. 41)

Finally, we can always view Zeyer's artistic way as the pilgrimage to "other worlds" that has a form of mysteries. We can understand these mysteries in his work, as a symbolic return to inner levels of human soul and the soul of the world, when the writer by the main characters of his poems, short stories, long short stories and novels rediscovers forgotten spiritual riches as a way to real higher reality.

\section{References}

A u g u s t a V. M., 1918, Mystika Julia Zeyera. Praha: Bradáč.

H r a bá k J., 1983, Umělec slova. In Zeyer J., Román o věrném přátelství Amise a Amila. Praha: Odeon, s. 263-277.

Julius Zeyer, lumírovský básník v duchovním dèni Evropy, 2009, Brno: Host.

J u r č i n o vá E., 1941, Julius Zeyer-Život českého básníka. Praha: Topičova edice.

Karáse k ze Lvovi c J., 1926, Renaissanční touhy v umění. Kritické studie. Praha: Aventinum.

K r e j čí F. V., 1901, Julius Zeyer - Kritická studie. Praha: Hejda a Tuček.

K u c h a ř L.1999, Dialogy o kráse a smrti: studie a materiály k české literatuře přelomu 19. a 20. století, Brno: Host.

K v a p i 1 J. Š., 1942, Gotický Zeyer. Praha: V. Petr. 
M a r t e n M., 1910, Julius Zeyer. Praha: Kamilla Neumannová.

M a r t e n M., 1916, Akkord: Mácha-Zeyer-Březina: Essaie. Praha: B. Kočí.

M e r h a u t L., 1994, Cesty stylizace: (stylizace, »okraj« a mystifikace v české literature prelomu devatenáctého a dvacátého století), Praha: Ústav pro českou literaturu Akademie věd České republiky.

P a p o u š e k V. Slovník a vize (Reprezentace universa a univerzality v řeči symbolistů). WORLD LITERATURE STUDIES, Časopis pre výskum svetovej literatúry. 2012, 4, 1, s. 43-53.

Přátelé Zeyer - Herites, 1941, usp. Božena Heritesová, Praha: Topičova edice.

Prátelství básnikù. Vzájemná korespondence Karla Dostála-Lutinova s Juliem Zeyerem a Otokarem Březinou, 1997, Podle rukopisné edice Oldřicha Svozila zpracoval S. Batůšek. Brno: Host.

P y n s e n t R. B., 1973, The Path to Decadence. Paris: Mouton, The Hague.

Ř e z n í č k ov á L., 2004, Moderna a historismus. Praha: Libri.

Š a 1 d a F.X., 1951, Kritické projevy - 5. Soubor díla F. X. Šaldy, sv. 14. K vydání prripravil Emanuel Macek. Praha: Společnost F. X. Saldy, Melantrich.

TEXTY, SNY OBRAZY, sborník zeyerovských přednášek, 1997, usp. T. Vlček. Písek: Městské muzeum ve Vodňanech a Společnost Julia Zeyera.

Ve stínu Orfea, Julius Zeyer a rodina Kalašových v dopisech, 1949, usp. J. Zikmund. Praha: nakl. B. Rupp.

V o b o rn í k J., 1907, Julius Zeyer. Spisy J. Zeyera. Praha: Česká grafická unie.

V o j t ě c h D., 2008, Vášeň a ideál. Na křižovatkách moderny. Praha: Academia.

V o r e 1 J., 2012, Od dekadence k teurgii: (esteticko-filozofická hledáni české a ruské literatury prelomu 19. a 20. století). Ostrava: FF OU.

W i e n d 1 J., 2007, Vizionáři a vyznavači. Kotázce sepětí rádu umění a života v české poezii první poloviny 20. století. Praha: Dauphin.

Z e y e r J., 1901-1906a, Dưm U tonoucí hvězdy. In Spisy Julia Zeyera XXIV. Praha: Česká grafická unie.

Z e y e r J.,1901-1906b, Fantastické povídky (Z papiru na kornouty, Opálová miska Vánoční povídka, Na pomezi cizích světů). In Spisy Julia Zeyera VIII. Praha: Česká grafická unie.

Z e y e r J., 1901-1906c, Spisy Julia Zeyera XXXIV. Praha: Česká grafická unie.

Z e y e r J., 1905, Karolinská epopeja I. Spisy XIV. Praha: Česká grafická unie.

Z e y e r J., 1907, Báje Šošany. Spisy Julia Zeyera XXI. Praha: Česká grafická unie.

Z e y e r J., 1941, Troje paměti Vita Choráze. Básně/Lyrika a drobná Epika/. Praha: Česká grafická unie.

Z e y e r J., 1949, Ondřej Černyšev. Praha: Česká grafická unie.

Z e y e r J., 1961, Radúz a Mahulena. Praha: Odeon. 